\title{
Pengaruh Faktor-Faktor Fundamental dan Teknikal terhadap Dividend Payout Ratio
}

\author{
Nyi Raden Sella Ayu Ardiyanti ${ }^{1}$ \\ ${ }^{1}$ Universitas Pancasila, Jl. Srengseng Sawah, Jagakarsa, Jakarta Selatan 12640
}

I N F O A R T I K E L

JEL Classification:

G10

G32

Keywords :

cash ratio,

debt to equity ratio,

return on asstes,

earning per share,

inflasi suku bunga,

and dividend payout ratio

\section{A $B$ S T $T$ R A C}

This study aims to examine the extent to which the implementation of the cash ratio, debt to equity ratio, return on asstes, earning per share, inflation and interest and dividend payout ratio impact on the results of an empirical study on manufacturing companies in indonesia stock exchange during the period 2010-2014. The sample used in this study as many as 11 companies for 5 years consecutive issued dividend. The analysis technique used in this research is multiple linear regression and hypothesis testing using t-statistic to test the partial regression coefficient and f-statistic to test the feasibility of the research model with 5\% level of significance. It also conducted a classic assumption test including normality test, multicolinearity test, heteroscedasticity test and autocorrelation test. Results of the analysis showed that the variable cash ratio, return on asstes, and earning per share, positive and significant impact on the dividend payout ratio, while the variable debt to equity ratio, inflation and interest rate negative and not significant to the dividend payout ratio.

\section{A B S T R A K}

Riset ini bertujuan untuk meneliti sejauh mana implementasi cash ratio, debt to equity ratio, return on asstes, earning per share, Inflasi dan Suku Bunga dan dampaknya pada dividend payout ratio hasil studi empiris pada perusahaan Manufaktur di Bursa Efek Indonesia selama periode 2010-2014. Sampel yang digunakan dalam penelitian ini sebanyak 11 perusahaan yang selama 5 tahun berturut-turut mengeluarkan deviden Teknik analisis yang digunakan dalam penelitian ini adalah regresi linear berganda dan uji hipotesis menggunakan t-statistik untuk menguji koefisien regresi parsial serta f-statistik untuk menguji kelayakan model penelitian dengan level of significance 5\%. Selain itu juga dilakukan uji asumsi klasik yang meliputi uji normalitas, uji multikolinieritas, uji heteroskedastisitas dan uji autokorelasi. Hasil analisis menunjukan bahwa variabel cash ratio, return on asstes, dan earning per share, berpengaruh positif dan signifikan terhadap dividend payout ratio, sedangkan variabel debt to equity ratio, Inflasi dan Suku Bunga berpengaruh negatif dan tidak signifikan terhadap dividend payout ratio.

\section{Pendahuluan}

Dalam menanamkan modalnya, investor akan mempertimbangkan dengan sebaik-baiknya

ke perusahaan mana modal akan ditanamkan. Dalam kondisi ini setiap perusahaan dituntut untuk dapat beroperasi dengan tingkat efisiensi yang

*Email Korespondensi:Inyi_raden@ymail.com 
cukup tinggi agar tetap mempunyai keunggulan dan daya saing dalam upaya menghasilkan laba bersih seoptimal mungkin. Menurut Darmadji (2006:177) Perusahaan yang akan membagikan dividen dihadapkan pada berbagai macam pertimbangan antara lain perlunya menahan sebagian laba untuk reinvestasi yang mungkin lebih menguntungkan, kebutuhan dana perusahaan, likuiditas perusahaan, sifat pemegang saham, target tertentu yang berhubungan dengan rasio pembayaran dividen dan faktor lain yang berhubungan dengan kebijakan dividen.

Berdasarkan keadaan perekonomian diindonesia selama 2010-2014 maka kebijakan dividen perusahaan sendiri dapat tergambar pada Dividend Payout Ratio, yaitu persentase laba yang dibagikan dalam bentuk dividen tunai, artinya besar kecilnya Dividend Payout Ratio akan mempengaruhi keputusan investasi para pemegang saham dan disisi lain berpengaruh pada kondisi keuangan perusahaan. Pertimbangan mengenai Dividend Payout Ratio ini diduga sangat berkaitan dengan kinerja keuangan perusahaan. Bila kinerja keuangan perusahaan bagus maka perusahaan tersebut akan mampu menetapkan besarnya Dividend Payout Ratio sesuai dengan harapan pemegang saham dan tentu saja tanpa mengabaikan kepentingan perusahaan untuk tetap sehat dan tumbuh.

\section{Telaah Teori dan Pengembangan Hipotesis}

Menurut Sawir (2005:4), Analisis fundamental adalah aktivitas meneliti kondisi keuangan untuk mengetahui lebih baik tentang operasi perusahaan yang mengeluarkan saham. Analisis fundamental merupakan suatu proses yang memerlukan waktu yang lama dengn menyelidiki keadaan ekonomi, politik, sosial, industri dan laporan-laporan keuangan perusahaan.

Menurut Husnan (2001:315) analisa Teknikal adalah sebuah metode peramalan atau estimasi pergerakan harga dengan melihat data historis harga yang terjadi di pasar. Dalam menggunakan metode analisa teknikal apapun adalah kembali ke dasar teorinya, yang secara metodologi telah terbukti kinerja untuk periode waktu yang signifikan.

Menurut Darmadji (2005:177) Dividend Payout Ratio adalah persentase dari pendapatan yang akan dibayarkan kepada pemegang saham sebagai dividen tunai. Jika rasio yang ditunjukkan dalam dividend payout ratio cukup tinggi, terdapat indikasi bahwa perusahaan membayarkan dividen dalam jumlah besar namun jika hanya membayarkan sedikit bagian dari laba perusahaan untuk pembayaran dividen tunai,

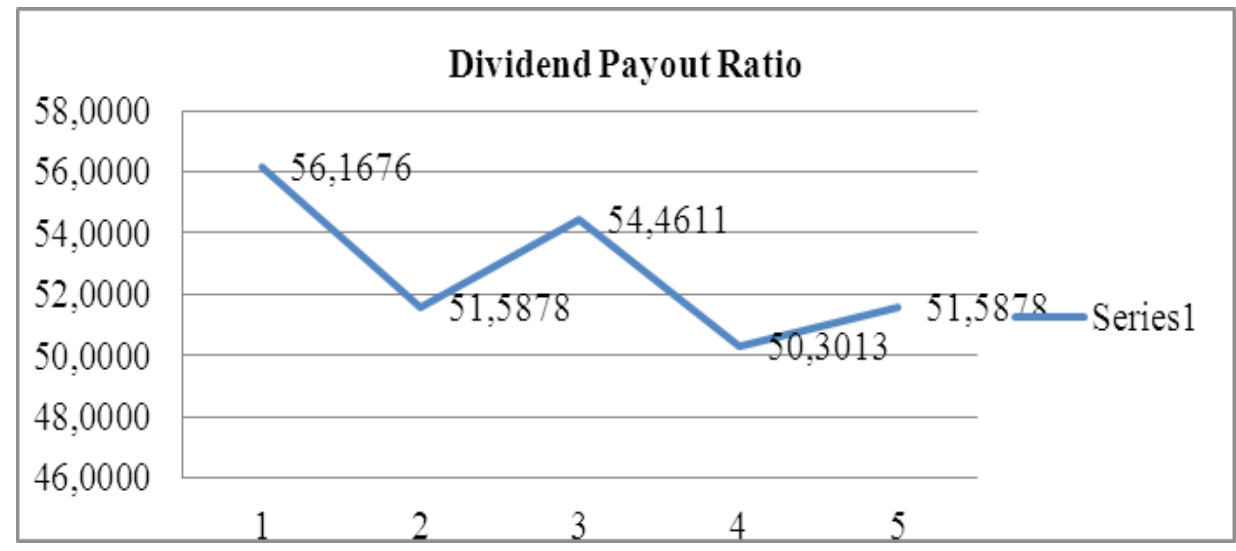

Gambar 1. Grafik DPR periode 2010-2014 
menandakan sisa pembayaran tersebut digunakan untuk kegiatan operasional perusahaan yang kemudian akan sangat membantu perusahaan dalam menaikkan harga saham biasa perusahaan setelah tanggal pembagian dividen.

Menurut Harahap (2009:85) Cash Ratio merupakan salah satu ukuran dari rasio likuiditas yang merupakan kemampuan perusahaan memenuhi kewajiban jangka pendeknya melalui sejumlah kas dan setara kas (giro atau simpanan lain di bank yang dapat ditarik setiap saat) yang dimiliki perusahaan. Semakin tinggi Cash Ratio menunjukkan kemampuan kas perusahaan untuk memenuhi (membayar) kewajiban jangka pendeknya.

Menurut Riyanto (2000:54), salah satu rasio yang termasuk dalam rasio solvabilitas atau leverage adalah Debt to Equity Ratio. Rasio ini digunakan untuk mengetahui berapa bagian dari setiap modal sendiri yang dijadikan jaminan untuk keseluruhan hutang perusahaan atau untuk menilai banyaknya hutang yang dipergunakan oleh perusahaan.

Menurut Ang (1997) Return on Asset adalah tingkat keuntungan bersih yang berhasil diperoleh perusahaan dalam menjalankan operasionalnya. Return On Asset diukur dari laba bersih setelah pajak terhadap total assetnya yang mencerminkan kemampuan perusahaan dalam penggunaan investasi yang digunakan untuk operasi perusahaan dalam rangka menghasilkan probabilitas perusahaan. Menurut Halim (2003:12), Earning Per Share (EPS) adalah perbandingan antara keuntungan bersih setelah pajak yang diperoleh emiten dengan jumlah saham yang beredar.

Menurut Bank Indonesia, Indikator yang sering digunakan untuk mengukur tingkat inflasi adalah indeks harga konsumen (IHK). Perubahan IHK dari waktu ke waktu menunjukkan pergerakan harga dari paket barang dan jasa yang dikonsumsi masyarakat. Sejak awal Juli 2005, Bank Indonesia menggunakan mekanisme BI Rate (suku bunga $\mathrm{BI}$ ), yaitu $\mathrm{BI}$ mengumumkan target suku bunga SBI yang diinginkan oleh Bank Indonesia untuk pelelangan pada masa periode tertentu. BI Rate ini kemudian yang digunakan sebagai acuan para pelaku pasar dalam mengikuti pelelangan. BI Rate digunakan sebagai acuan dalam pelaksanaan operasi pengendalian moneter untuk mengarahkan agar rata-rata tertimbang suku bunga SBI satu bulan hasil lelang operasi pasar terbuka berada di sekitar BI Rate. Selanjutnya suku bunga SBI satu bulan diharapkan mempengaruhi suku bunga pasar uang antar bank dan suku bunga jangka yang lebih panjang.

\section{Hubungan Konseptual Cash Ratio terhadap Dividend Payout Ratio}

Menurut Susan Irawati (2006:27) Cash Ratio adalah rasio yang mengukur kemampuan perusahaan untuk membayar utangnya yang segera harus dipenuhi dengan kas yang tersedia didalam perusahaan dan efek yang dapat segera diuangkan. Semakin tinggi nilai Cash Ratio menunjukkan kemampuan perusahaan dalam memenuhi kewajiban jangka pendeknya, maka semakin besar Cash Ratio perusahaan maka semakin besar kemampuan perusahaan dalam membayar dividen. Berdasarkan hasil penelitian yang dilakukan oleh Rowland, dkk (2014) bahwa Cash Ratio tidak berpengaruh terhadap Dividend Payout Ratio.

Cash Ratio perusahaan merupakan faktor penting yang harus dipertimbangkan sebelum mengambil keputusan untuk menetapkan besarnya dividen yang akan dibayarkan kepada para pemegang saham. Dividen merupakan cash outflow, maka makin kuatnya posisi kas perusahaan berarti makin besar kemampuan perusahaan membayar dividen. Cash Ratio merupakan salah satu ukuran dari likuiditas (liquidity ratio) yang merupakan kemampuan perusahaan dalam memenuhi kewajiban jangka pendeknya (current liability) melalui sejumlah kas (dan setara kas, seperti giro atau simpanan lain di bank yang dapat ditarik setiap saat) yang dimiliki perusahaan.

\section{Hubungan Konseptual Debt to Equity Ratio terhadap Dividend Payout Ratio}

Menurut Sawir (2000:13) menjelaskan 
bahwa Debt to Equity Ratio adalah rasio yang menggambarkan perbandingan utang dan ekuitas dalam pendanaan perusahaan dan menunjukan kemampuan modal sendiri perusahaan tersebut untuk memenuhi seluruh kewajibannya. Kreditur melihat ekuitas atau dana yang diberikan oleh pemilik sebagai batas pengaman. Dengan menghimpun danamelaluihutang maka pemegang saham dapat mengendalikan perusahaan dengan jumlah investasi ekuitas yang terbatas. Rasio ini dapat menggambarkan potensi manfaat dan resiko yang berasal dari penggunaan utang.

Berdasarkan penelitian yang dilakukan oleh Marietta dan Sampurno (2013) Debt To Equity Ratio tidak berpengaruh terhadap Dividend Payout Ratio, sedangkan penelitian yang telah dilakukan oleh Rowland,dkk (2014) dikatakan bahwa Debt To Equity Ratio berpengaruh signifikan terhadap Dividend Payout Ratio. Debt to Equity Ratio (DER) merupakan suatu rasio keuangan yang mengindikasikan proporsi hubungan antara hutang dan ekuitas yang digunakan untuk membiayai aset perusahaan. Peningkatan hutang pada gilirannya akan mempengaruhi besar kecilnya laba bersih yang tersedia bagi para pemegang saham, termasuk dividen yang diterima karena kewajiban untuk membayar hutang lebih diutamakan daripada pembagian dividen.

\section{Hubungan Konseptual Return on Asset terhadap Dividend Payout Ratio}

Menurut Hanafi dan Halim (2003:27), Return on Assets merupakan rasio keuangan perusahaan yang berhubungan dengan profitabilitas mengukur kemampuan perusahaan menghasilkan keuntungan atau laba pada tingkat pendapatan, aset dan modal saham tertentu. Semakin besar nilai ROA yang dihasilkan perusahaan maka semakin besar kemampuan perusahaan dalam membagikan dividen kepada pemegang saham (stakeholders).

Berdasarkan penelitian yang dilakukan oleh Marietta dan Sampurno (2013), menunjukan bahwa Return on Assets memiliki pengaruh yang signifikan terhadap Dividend Payout Ratio
(DPR). ROA merupakan rasio keuangan yang digunakan untuk mengukur tingkat dengan mana aktiva telah digunakan untuk menghasilkan laba. Semakin besar ROA menunjukkan kinerja perusahaan yang semakin baik, karena tingkat pengembalian investasi semakin besar. Sehingga meningkatnya ROA juga akan meningkatkan pendapatan dividen. Kemampuan perusahaan dalam memperoleh laba merupakan indikator utama dalam kemampuan perusahaan untuk membayar dividen, sehingga profitabilitas sebagai faktor penentu terpenting terhadap dividen.

\section{Hubungan Konseptual Earnings Per Share dan Dividend Payout Ratio}

$$
\text { Menurut Baridwan }
$$
Earnings Per Share adalah Jumlah pendapatan yang diperoleh dalam satu periode untuk tiap lembar saham yang beredar, dan akan dipakai oleh pimpinan perusahaan untuk menentukan besarnya dividen yang akan dibagikan. Semakin tinggi nilai EPS yang dihasilkan perusahaan, maka semakin besar kemampuan perusahaan dalam membagikan dividen. Berdasarkan penelitian yang telah dilakukan oleh Ebenezer (2013), menunjukkan bahwa Earnings Per Share berpengaruh signifikan terhadap Dividend Payout Ratio.

Pendapatan per lembar saham (Earnings Per Share) merupakan total keuntungan yang diperoleh investor untuk setiap lembar sahamnya. Total keuntungan tersebut diukur dari rasio antara laba bersih setelah pajak (Earnings After Tax) terhadap jumlah lembar saham yang beredar (outstanding share). Laba bersih yang diperhitungkan tersebut setelah dikurangi dengan dividen untuk para pemegang saham prioritas/ minoritas (preffered stock). Semakin besar earning after tax maka pendapatan dividen kas per lembar saham (cash dividend per share) yang akan diterima oleh para pemegang saham biasa (common stock) juga semakin besar. Hal tersebut dengan asumsi jika dividen bagi para pemegang saham minoritas dan jumlah saham yang beredar (saham biasa) relatif tetap.

Dalam menanamkan modal di perusahaan 
emiten, pemegang saham mempunyai harapan keuntungan dari modal yang ditanamkannya itu. Dalam hal ini ada dua jenis dividen yang biasa diperoleh pemegang saham, yaitu dividen kas dan non kas. Dividen kas (cash dividend) adalah dividen yang dibayar oleh emiten kepada pemegang saham dalam bentuk uang tunai. Dividen non kas adalah dividen yang dibayarkan dalam bentuk saham dengan proporsi tertentu. Contoh dividen non kas adalah dividen saham (stock dividend) dan dividen aktiva.

\section{Hubungan Konseptual Inflasi dan Dividend Payout Ratio}

Meningkatnya sukubunga secaralangsung akan meningkatkan beban bunga. Perusahaan yang memiliki leverage yang tinggi akan mendapatkan dampak yang sangat berat terhadap kenaikan tingkat bunga. Harga bahan baku juga akan meningkat, jika kenaikan biaya ini tidak dapat diserap oleh harga jual terhadap konsumen, maka profitabilitas perusahaan akan menurun. Menurunnya profitabilitas ini, akan mengakibatkan dampak yang signifikan terhadap pendapatan deviden yang harus diterima oleh investor, yang gilirannya investasipada saham di pasar modal menjadi hal yang kurang menarik. Pada akhirnya investor akan berpindah ke jenis investasi yang lain, yang memberikan return yang lebih baik dalam hal ini bunga yang tinggi, misalnya deposito.

Berdasarkan hal itu diketahui secara tidak langsung inflasi berpengaruh terhadap harga saham. Meningkatnya inflasi secara relatif adalah signal negatif bagi para investor. Terutama bagi perusahaan yang memiliki solvabilitas yang tinggi karena dapat mengurangi profit dan akhirnya harga saham pun akan turun. Selain itu tingginya tingkat inflasi pada tahun tersebut juga dipicu oleh adanya ekspektasi dari masyarakat bahwa rupiah akan semakin terdepresiasi dimasa yang akan datang dan akibatnya tingkat harga akan terus naik.

\section{Hubungan Konseptual Suku Bunga dan Dividend Payout Ratio}

Investasi melalui pasar modal selain memberikan hasil, juga mengandung resiko. Besar kecilnya resiko di pasar modal sangat di pengaruhi oleh keadaan negara khususnya di bidang ekonomi, politik dan sosial. beberapa faktor yang mempengaruhi dividen adalah Profitabilitas, Tingkat suku bunga SBI, inflasi dan nilai tukar. Oleh karena itu, tujuan dari penelitian ini adalah untuk mengetahui pengaruh tingkat bunga SBI, terhadap naik turunnya dividen. Tingkat bunga SBI adalah Variabel yang paling dominan berpengaruh terhadap dividen.

\section{Metode}

Objek dalam penelitian ini adalah Cash Ratio (CR), Debt to Equity Ratio (DER), Return On Asset (ROA), Earning Per Share (EPS), Inflasi, Suku Bunga dan variabel Dependent ialah Dividend Payout Ratio (DPR). Metode penelitian yang digunakan dalam penelitianiniadalahmetode kuantitatif yang berdasarkan pada data sekunder berupa laporan keuangan dengan data Dividend Payout Ratio (DPR) pada masing-masing perusahaan manufaktur yang terdaftar di BEI. berdasarkan fungsinya penelitian ini merupakan jenis penelitian kausalitas yang bertujuan untuk mendeskriptifkan hubungan sebab akibat antara variabel dan menarik kesimpulan dari hubungan antara variabel tersebut.

Penelitian ini yang menjadi populasi penelitian adalah perusahaan manufaktur yang terdaftar di Bursa Efek Indonesia tahun 20102014. Alasan digunakannya data mulai dari tahun 2010 adalah adanya pergerakan fluktuatif pada Dividend Payout Ratio (DPR), dan data yang digunakan adalah laporan keuangan lima tahun terakhir. Sedangkan sampel adalah sebagian dari populasi yang diteliti, dalam penelitian ini sampel diambil dengan menggunakan purposive sampling dengan tujuan untuk mendapatkan sampel yang representative. Teknik pengelolahan data yang digunakan dalam penelitian ini adalah persamaan regresi linear berganda yang bertujuan untuk melihat apakah variabel independen (X) berpengaruh secara signifikan terhadap variabel dependen (Y). Bentuk umum persamaan linear 
berganda dengan menggunakan lima variabel adalah sebagai berikut:

\begin{tabular}{|c|c|c|}
\hline \multicolumn{3}{|l|}{ Keterangan } \\
\hline $\mathrm{Y}$ & $=$ & $\begin{array}{l}\text { Dividend Payout Ratio } \\
\text { (DPR) }\end{array}$ \\
\hline $\mathrm{a}$ & $=$ & konstanta \\
\hline $\mathrm{b} 1, \mathrm{~b} 2, \mathrm{~b} 3, \mathrm{~b} 4$ & $=$ & koefisien regresi \\
\hline XI & $=$ & Cash Ratio (CR) \\
\hline $\mathrm{X} 2$ & $=$ & $\begin{array}{l}\text { Debt to Equity Ratio } \\
\text { (DER) }\end{array}$ \\
\hline $\mathrm{X} 3$ & $=$ & Return On Asset (ROA) \\
\hline $\mathrm{X} 4$ & $=$ & Earning Per Share (EPS) \\
\hline $\mathrm{X} 5$ & $=$ & Inflasi \\
\hline $\mathrm{X} 6$ & $=$ & Suku Bunga \\
\hline $\mathrm{e}$ & & erorr term, diasumsikan 0 \\
\hline
\end{tabular}

Pengujian statistik dilakukan dengan 2 tahap. Pertama, uji asumsi klasik, dan kedua, uji hipotesisi penelitian. Pengujian hipotesis penelitian diawali dengan uji model dengan Uji F dan Uji koefisien determinasi. Pembuktian hipotesis penelitian dilakukan dengan Uji t.

\section{Hasil Penelitian dan Pembahasan}

Pengujian hipotesis dilakukan dengan uji regresi linier berganda. Uji asumsi klasik memberikan hasil bahwa model yang diuji telah memenuhi asumsi klasik yang mencakup normalitas, multikolineariras, heteroskedastisitas dan autokorelasi.
Berdasarkan hipotesis alternatif (H1) menyatakan bahwa Cash Ratio berpengaruh signifikan terhadap Dividend Payout Ratio. Pada parameter statistik hasil perhitungan uji-t diperoleh nilai t hitung sebesar 2,930 dengan nilai signifikansi sebesar 5\%. Karena nilai t hitung 2,930 lebih besar dari nilai t tabel 2,010 dan nilai signifikansi lebih kecil dari 5\% yaitu sebesar $0,5 \%$. Dengan demikian dapat dinyatakan bahwa Cash Ratio berpengaruh positif dan signifikan terhadap Dividend Payout Ratio, dan dapat disimpulkan bahwa Hipotesis pertama (H1) diterima dan Hipotesis (Ho) ditolak.

Berdasarkan hipotesis alternatif (H2) menyatakan bahwa Debt to Equity Ratio berpengaruh signifikan terhadap Dividend Payout Ratio. Pada parameter statistik hasil perhitungan uji-t diperoleh nilai t hitung sebesar 1,585 dengan nilai signifikansi sebesar 5\%. Karena nilai $\mathrm{t}$ hitung 1,585 lebih kecil dari nilai t tabel 2,010 dan nilai signifikansi lebih besar dari $5 \%$ yaitu sebesar $12 \%$. Dengan demikian dapat dinyatakan bahwa Debt to Equity Ratio tidak berpengaruh signifikan terhadap Dividend Payout Ratio, dan dapat disimpulkan bahwa Hipotesis kedua (H2) ditolak dan Hipotesis (Ho) diterima.

Hipotesis alterantif (H3) menyatakan bahwa Return On Assets berpengaruh signifikan terhadap Dividend Payout Ratio. Pada parameter statistik hasil perhitungan uji-t diperoleh nilai $\mathrm{t}$ hitung sebesar 2,317 dengan nilai signifikansi sebesar 5\%. Karena nilai t hitung 2,317 lebih

Tabel 1. Rangkuman Hasil Pengujian

\begin{tabular}{lrrrrr}
\hline Variabel & & & & & \\
\hline CR & 27.648 & 9.436 & 0.524 & 2.93 & 0.005 \\
DER & 16.775 & 10.585 & 0.286 & 1.585 & 0.12 \\
ROA & 0.661 & 0.285 & 0.375 & 2.317 & 0.025 \\
EPS & 0.007 & 0.003 & 0.368 & 2.242 & 0.03 \\
Inflasi & 12.999 & 7.219 & 0.244 & 1.801 & 0.078 \\
Suku Bunga & -0.058 & 3.706 & -0.002 & -0.016 & 0.987 \\
(Constant) & -78.23 & 52.556 & & -1.489 & 0.143 \\
R Square & 0.323 & & & & \\
Adjusted R-Square & 0.238 & & & & \\
F-hitung & 3.811 & & & & \\
Sig-F & 0.003 & & & & \\
\hline
\end{tabular}


besar dari nilai $t$ tabel 2,010 dan nilai signifikansi lebih kecil dari 5\% yaitu sebesar 2,5\%. Dengan demikian dapat dinyatakan bahwa Return On Assets berpengaruh positif signifikan terhadap Dividend Payout Ratio, dan dapat disimpulkan bahwa Hipotesis ketiga (H3) diterima dan Hipotesis (Ho) ditolak.

Hipotesis alternatif (H4) menyatakan bahwa Earning Per Share berpengaruh signifikan terhadap Dividend Payout Ratio. Pada parameter statistik hasil perhitungan uji-t diperoleh nilai $\mathrm{t}$ hitung sebesar 2,242 dengan nilai signifikansi sebesar 5\%. Karena nilai t hitung 2,242 lebih besar dari nilai $t$ tabel 2,010 dan nilai signifikansi lebih kecil dari 5\% yaitu sebesar 3\%. Dengan demikian dapat dinyatakan bahwa Earning Per Share berpengaruh positif signifikan terhadap Dividend Payout Ratio, dan dapat disimpulkan bahwa Hipotesis keempat (H4) diterima dan Hipotesis (Ho) ditolak.

Hipotesis alterntif (H5) menyatakan bahwa Inflasi berpengaruh signifikan terhadap Dividend Payout Ratio. Pada parameter statistik berdasarkan hasil perhitungan uji-t diperoleh nilai t hitung sebesar 1,801 dengan nilai signifikansi sebesar 5\%. Karena nilai t hitung 1,801 lebih kecil dari nilai $t$ tabel 2,010 dan nilai signifikansi lebih besar dari 5\% yaitu sebesar 7,8\%. Dengan demikian dapat dinyatakan bahwa inflasi tidak berpengaruh signifikan terhadap Dividend Payout Ratio, dan dapat disimpulkan bahwa Hipotesis kelima (H5) ditolak dan Hipotesis (Ho) diterima.

Hipotesis alternatif (H6) menyatakan bahwa Suku Bunga berpengaruh signifikan terhadap Dividend Payout Ratio. Pada parameter statistik hasil perhitungan uji-t diperoleh nilai $t$ hitung sebesar -0,016 dengan nilai signifikansi sebesar 5\%. Karena nilai t hitung $-0,016$ lebih kecil dari nilai t tabel 2,010 dan nilai signifikansi lebih besar dari 5\% yaitu sebesar 98,7\%. Dengan demikian dapat dinyatakan bahwa Suku Bunga tidak berpengaruh signifikan terhadap Dividend Payout Ratio, dan dapat disimpulkan bahwa Hipotesis keenam (H6) ditolak dan Hipotesis (Ho) diterima.

Hasil pengujian hipotesis pertama (H1) menunjukkan bahwa Cash Ratio berpengaruh positif dan signifikan secara statistik terhadap Dividend Payout Ratio. Variabel Cash Ratio memiliki koefisien positif, ini berarti bahwa apabila Cash Ratio meningkat maka kemungkinan dibagikannya dividen akan semakin besar. Hasil pengujian ini konsisten dengan hasil penelitian yang dilakukan oleh Ebenezer (2013) yang menguji Determinants of dividend payout policy of some selected manufacturing firms listed on the Ghana Stock Exchange. Hasil penelitian tersebut menunjukkan bahwa variabel Cash Ratio berpengaruh positif terhadap Dividend Payout Ratio. Nilai positif dalam variabel Cash Ratio ini menunjukkan bahwa adanya peningkatan jumlah kas dan setara kas dalam perusahaan maka akan meningkatkan dividend payout ratio.

Semakin likuid perusahaan maka akan semakin besar kemungkinan pembayaran yang dilakukanolehperusahaantersebut. Meningkatnya Cash Ratio juga dapat meningkatkan harapan investor terhadap kemampuan perusahaan untuk membagikan dividen. Meningkatnya Cash Ratio juga dapat meningkatkan harapan investor terhadap kemampuan perusahaan untuk membagikan dividen. Namun penelitian ini tidak sesuai dengan peneitian yang dilakukan oleh Agung Hardinugroho dengan penelitian Analisis Faktor-faktor yang mempengaruhi DPR pada perusahaan Manufaktur di BEI periode 20092010, dimana dari hasil penelitiannya dijelaskan bahwa Cash Ratio tidak mempunyai pengaruh yang signifikan terhadap DPR. Namun hal ini tidak didukung oleh Mollah dan Keasen (2000) yang menyatakan bahwa Cash Ratio merupakan variabel penting yang dipertimbangkan oleh manajemen dalam penentuan kebijakan dividen. Pembayaran dividen merupakan arus kas keluar sehingga free cash flow yang tinggi akan memungkinkan perusahaan lebih berfokus pada pembiayaan dividen atau pelunasan hutang untuk mengurangi biaya keagenan.

Hasil pengujian hipotesis kedua (H2) menunjukkan bahwa Debt to Equity Ratio tidak berpengaruh terhadap Dividend Payout Ratio. Sehingga Semakin rendah DER belum tentu semakin tinggi kemampuan perusahaan untuk membayar seluruh kewajibannya. 
Menurut Sawir (2000:13) ada beberapa faktor yang mempengaruhi kebijakan dividen yaitu kebutuhan dana bagi perusahaan, likuiditas perusahaan, dan pengendalian perusahaan. Dilihat dari perkembangan periode pengamatan, perusahaan manufaktur rata-rata memiliki nilai Debt to Equity Ratio yang rendah, hal ini menunjukkan bahwa perusahaan manufaktur lebih menyukai pembiayaan dengan modal sendiri daripada menggunakan dana dari pihak luar. Hal tersebut sejalan dengan Pecking Order Theory yang menyatakan bahwa perusahaan menyukai Internal Financing (pendanaan dari hasil operasi perusahaan berwujud laba ditahan) daripada pendanaan dari luar. Hal ini tidak terlepas dari usaha untuk meningkatkan kredibilitas perusahaan di mata pihak eksternal karena hutang memberikan risiko yang tinggi, artinya perusahaan harus mampu mengambil keputusan di tengah tawaran akan manfaat dari leverage atau menjaga kesejahteraan pemegang saham, dengan menjauhkannya dari risiko tersebut. Hasil pengujian penelitian ini konsisten dengan hasil penelitian sebelumnya yang dilakukan oleh Marietta dan Sampurno (2013) yang meneliti tentang Pengaruh Cash Ratio, Return On Assets, Growth, Firm Size, Debt to Equity Ratio Terhadap Dividend Payout Ratio : ( Studi Pada Perusahaan Manufaktur Yang Terdaftar di Bursa Efek Indonesia Tahun 20082011), penelitian tersebut menyimpulkan bahwa kebijakan hutang (diproksi dengan leverage) tidak berpengaruh terhadap Dividend Payout Ratio. Hasil penelitian ini juga mendukung penelitian yang dilakukan Rahayuningtyas dkk (2014) yang meneliti tentang Pengaruh RasioRasio keuangan terhadap Dividend Payout Ratio (DPR) (Studi Pada Perusahaan Yang Listing Di BEI Tahun 2009 - 2011).

Pada hipotesis ketiga (H3) menunjukan bahwa variabel Return On Asset berpengaruh positif dan signifikan terhadap Dividend Payout Ratio, tanda positif pada koefisien regresi menunjukkan bahwa apabila Return On Asset meningkat maka Dividend Payout Ratio juga meningkat. Hasil penelitian menunjukkan bahwa pengaruh positif variabel Return On Asset terhadap Dividend Payout Ratio menjelaskan bahwa tingkat profitabilitas perusahaan akan berdampak pada peningkatan pembagian dividen yang akan dibayarkan. Tanda positif dalam penelitian ini sesuai dengan teori information content or signaling hypothesis yang dikemukan oleh Miller dan Mondigliani yang menyatakan bahwa kenaikan dividen merupakan suatu sinyal kepada para investor bahwa manajemen meramalkan suatu penghasilan yang baik di masa yang akan datang. Berdasarkan teori tersebut, dapat ditunjukkan bahwa penghasilan yang tinggi melalui asset yang dimiliki yang tercermin dari nilai Return On Asset menunjukkan pengaruh yang positif terhadap kebijakan dividen. Hal ini disebabkan oleh meningkatnya kemampuan perusahaan untuk menghasilkan laba yang tentunya akan meningkatkan nilai perusahaan dan memberikan sinyal baik kepada investor tentang kemampuan perusahaan untuk menghasilkan laba. Hasil penelitian ini konsisten dengan hasil penelitian sebelumnya yang dilakukan oleh Marietta dan Sampurno (2013) Namun hasil penelitian kali ini bertolak belakang dengan hasil penelitian sebelumnya. Damayanti dan Achyani (2006). Hasil penelitian ini konsisten dengan penelitian yang dilakukan oleh Rowland, dkk (2014).

Pada hipotesis keempat (H4) menunjukan bahwa variabel Earning Per Share berpengaruh positif dan signifikan terhadap Dividend Payout Ratio, tanda positif pada koefisien regresi menunjukkan bahwa apabila Earning Per Share meningkat maka Dividend Payout Ratio juga meningkat. Hasil penelitian menunjukkan bahwa pengaruh positif variabel Earning Per Share terhadap Dividend Payout Ratio menjelaskan bahwa tingkat profitabilitas perusahaan akan berdampak pada peningkatan pembagian dividen yang akan dibayarkan. Earning Per Share digunakan mengukur kemampuan perusahaan dalam mencetak laba berdasarkan saham yang dimiliki. Angka Earning Per Share juga digunakan dalam publikasi mengenai kinerja perusahaan yang menjual sahamnya kepada masyarakat umum. Menurut Sawidji (2005:59) Perhitungan Earning Per Share mempunyai 
beberapa tujuan yaitu untuk melihat kemajuan dan operasi perusahaan, menentukan harga pasar saham, dan menentukan besarnya dividen yang akan dibagi. Hasil penelitian ini sesuai dengan penelitan Ebenezer (2013).

Pada hipotesis kelima (H5) menunjukan bahwa variabel Inflasi tidak berpengaruh signifikan terhadap Dividend Payout Ratio, Sehingga Semakin rendah Inflasi belum tentu semakin tinggi kemampuan perusahaan untuk membayar seluruh kewajibannya. Inflasi adalah kecenderungan terjadinya peningkatan harga produk secara keseluruhan. Inflasi tinggi dapat mengurangi tingkat pendapatan riil yang diterima investor dari investasinya. Menurut Sukirno (2008:14) Inflasi dapat meningkatan pendapatan perusahaan, di satu sisi juga meningkatkan biaya operasional. Jika peningkatan biaya produksi lebih tinggi dari peningkatan inflasi secara relatif merupakan sinyal negatif bagi pemodal di pasar modal. Hasil penelitian ini sesuai dengan Sugiharti Binastuti (2011) Faktor Fundamental terhadap Kebijakan Deviden Studi Kasus pada Perusahaan Manufaktur di BEI, dari hasil penelitan ini menghasilkan bahwa Inflasi tidak memiliki pengaruh terhdap Dividend Payout Ratio. Menurut Sukrino (2008:14) Inflasi dapat mempengaruhi kinerja perusahaan. Inflasi menyebabkan pendapatan masyarakat secara riil menurun, sehingga dengan inflasi yang tinggi menyebab-kan daya beli masyarakat turun. Inflasi tinggi mendorong investor untuk meminta tingkat pengembalian tinggi atas investasinya, sehingga inflasi tinggi mendorong investor untuk lebih memilih dividen yang tinggi, karena dividen dianggap lebih pasti dari pada capital gain. Inflasi tinggi mendorong perusahaan untuk membagi dividen dalam jumlah yang tinggi. Kebijakan ini memberikan persepsi kepada investor bahwa dengan tekanan inflasi, perusahaan masih bias mempertahankan keuntungan yang dapat dibagi kepada pemegang saham.

Pada hipotesis keenam (H6) menunjukan bahwa variabel Suku Bunga tidak berpengaruh signifikan terhadap Dividend Payout Ratio, Sehingga Semakin rendah Suku Bunga belum tentu semakin tinggi kemampuan perusahaan untuk membayar seluruh kewajibannya. Tingkat bunga yang terlalu tinggi akan mempengaruhi nilai sekarang aliran kas perusahaan, sehingga kesempatan investasi yang ada tidak akan menarik lagi. Tingkat bunga yang tinggi akan menyebabkan biaya modal yang ditanggung perusahaan tinggi, disisi lain tingkat bunga tinggi menyebabkan return yang disyaratkan dari investor atas suatu saham akan meningkat. Di samping itu dengan tingkat bunga tinggi dapat menyebabkan investor akan memindahkan investasi dari saham ke investasi tabungan atau deposito. Dapat disimpulkan bahwa tingkat suku bunga merupakan sinyal negatif terhadap dividen. Hasil penelitian ini sesuai dengan Sugiharti Binastuti (2011) Faktor Fundamental terhadap Kebijakan Deviden Studi Kasus pada Perusahaan Manufaktur di BEI, dari hasil penelitan ini menghasilkan bahwa Suku Bunga tidak memiliki pengaruh terhdap Dividend Payout Ratio. Tingkat suku bunga tinggi menunjukkan bahwa risiko investasi tinggi. Risiko investasi tinggi menyebabkan investor mengharapkan tingkat pengembalian tinggi juga. Pada saat tingkat suku bunga tinggi, investor mengharapkan tingkat pengembalian tinggi, sehingga memaksa pengelola perusahaan untuk membayar dividen tinggi. Hal ini sesuai dengan tradeoff antara risk and return yaitu semakin tinggi tingkat risiko maka tingkat pengembalian yang diharapkan dari investasi juga tinggi.

\section{Kesimpulan, Keterbatasan, dan Implikasi Hasil Penelitian}

Berdasarkan hasil penelitian dan pembahsan yang diuraikan pada bab sebelumnya, maka dapat ditarik kesimpulan sebagai berikut:

1. Cash Ratio berpengaruh positif dan signifikan terhadap Dividend Payout Ratio. Variabel Cash Ratio memiliki koefisien positif, hal ini berarti bahwa apabila Cash Ratio meningkat maka kemungkinan dibagikannya dividen akan semakin besar. Nilai positif dalam variabel Cash Ratio ini menunjukkan bahwa adanya peningkatan jumlah kas dan setara kas dalam perusahaan maka akan meningkatkan dividend payout ratio. Semakin likuid 
perusahaan maka akan semakin besar kemungkinan pembayaran yang dilakukan oleh perusahaan tersebut.

2. Debt to Equity Ratio tidak berpengaruh positif dan signifikan terhadap Dividend. Hal ini menunjukkan Semakin rendah DER belum tentu semakin tinggi kemampuan perusahaan untuk membayar seluruh kewajibannya. Dilihat dari perkembangan periode pengamatan, nilai positif pada Debt to Equity Ratio menunjukkan bahwa perusahaan manufaktur lebih menyukai pembiayaan dengan modal sendiri daripada menggunakan dana dari pihak luar.

3. Return on Asset berpengaruh positif dan signifikan terhadap Dividend Payout Ratio. Tanda positif pada koefisien regresi menunjukkan bahwa apabila Return On Asset meningkat maka Dividend Payout Ratio juga meningkat. Hasil penelitian menunjukkan bahwa pengaruh positif variabel Return On Asset terhadap Dividend Payout Ratio menjelaskan bahwa tingkat profitabilitas perusahaan akan berdampak pada peningkatan pembagian dividen yang akan dibayarkan.

4. Earning Per Share (EPS) berpengaruh positif dan signifikan terhadap Dividend Payout Ratio (DPR). Tanda positif pada koefisien regresi menunjukkan bahwa apabila Earning Per Share meningkat maka Dividend Payout Ratio juga meningkat.

5. Inflasi tidak berpengaruh positif dan signifikan terhadap Dividend Payout Ratio (DPR). Sehingga Semakin rendah Inflasi belum tentu semakin tinggi kemampuan perusahaan untuk membayar seluruh kewajibannya. Inflasi adalah kecenderungan terjadinya peningkatan harga produk secara keseluruhan. Inflasi tinggi dapat mengurangi tingkat pendapatan riil yang diterima investor dari investasinya.

6. Suku Bunga tidak berpengaruh positif dan signifikan terhadap Dividend Payout Ratio (DPR). Sehingga Semakin rendah Suku Bunga belum tentu semakin tinggi kemampuan perusahaan untuk membayar seluruh kewajibannya. Tingkat bunga yang terlalu tinggi akan mempengaruhi nilai sekarang aliran kas perusahaan, sehingga kesempatan investasi yang ada tidak akan menarik lagi. Tingkat bunga yang tinggi akan menyebabkan biaya modal yang ditanggung perusahaan tinggi, disisi lain tingkat bunga tinggi menyebabkan return yang disyaratkan dari investor atas suatu saham akan meningkat

7. Cash Ratio (CR), Debt to Equity Ratio (DER), Return On Assets (ROA), Earning Per Share (EPS), Inflasi dan Suku Bunga secara simultan memiliki pengaruh positif dan signifikan terhadap Dividend Payout Ratio (DPR).

Penelitian ini masih terdapat keterbatasanketerbatasan yang penting untuk diperhatikan oleh peneliti berikutnya, pertama, yaitu sampel masih terbatas pada perusahaan manufaktur di Bursa Efek Indonesia (BEI), dimungkinkan mengganti dengan perusahaan lain yang lebih luas untuk melihat pengaruh secara signifikan terhadap Dividend Payout Ratio (DPR). Kedua, dalam penelitian ini peneliti hanya menggunakan data tahunan dengan periode 5 tahun dan sampel perusahaan yang membagikan dividen secara konsisten atau berturut-turut selama periode penelitian

Saran bagi peneliti berikutnya adalah perlu dilakukan penelitian sejenis dengan interval waktu dan data yang berbeda, serta sampel yang lebih besar mengingat perkembangan dunia pasar modal di Indonesia, serta dapat menambah beberapa faktor yang mungkin dapat berpengaruh terhadap Dividend Payout Ratio (DPR). Bagi investor dalam melakukan pengambilan keputusan investasi saham pada sekuritas yang listing di Bursa Efek Indonesia sebaiknya tidak hanya melihat dari kondisi Inflasi yang rendah dan juga tingkat Suku Bunga yang tinggi, dikarenakan Inflasidapatmeningkatan pendapatan perusahaan, di satu sisi juga meningkatkan biaya operasional, Jika peningkatan biaya produksi lebih tinggi dari peningkatan inflasi secara relatif merupakan sinyal negatif bagi pemodal di pasar 
modal. Sedangkan tingkat Suku Bunga yang tinggi akan menyebabkan biaya modal yang ditanggung perusahaan tinggi dan hal ini akan mempengaruhi keputusan perusahaan dalam membagikan dividen.

\section{Daftar Pustaka}

Agnes Sawir. (2005). Analisis Kinerja Keuangan dan Perencanaan Keuangan Perusahaan, Jakarta: Gramedia Pustaka Utama.

Alfigari. (2002). Analisis Regresi Teori, Kasus, dan Solusi. Edisi kedua. Yogyakarta : BPFE.

Ang, Robert. (1997). Buku Pintar Pasar Modal Indonesia. Jakarta:Media Staff Indonesia.

Boanyah, Ayentimi. (2013) "Determinants of Dividend Payout Policy of Some SelectManufacturing Firms Listed on the Ghana Stock Exchange", Research Journal of Finance and Accounting Vol.4, No.5, p.49-60.

Brigham, Eguene \& Houston Joel, (2001) “Manajemen Keuangan”, Jakarta: Erlangga.

Darmadji dan Fakhrudin, (2006) Pasar Modal di Indonesia: Pendekatan Tanya Jawab, Jakarta: Salemba Empat.

Darsono, Azhari. (2005) Pedoman Praktis Memahami Laporan Keuangan. Yogyakarta: ANDI

Erni Masdupi. (2005) Analisis dampak struktur kepemilikan pada kebijakan hutang dalam mengkontrol konflik keagenan. Jurnal Ekonomi dan Bisnis Indonesia, Vol.2, No.1,hal.57-69

Gitman, Lawrence J. (2003) Principles Of Managerial Finance. Edisi kesepuluh. San Fransisco: Addison Wesley

Halim, Abdul. (2003). Analisis investasi. Jakarta: Salemba Empat.

Hanafi M. Mamduh. (2004). Manajemen Keuangan, Yogyakarta : BPFE.

Harahap, Sofyan Syafri. (2006) Analisis kritis atas laporan keuangan. Jakarta: PT Raja Grafindo Persada.

Hikmah, Astuti, (2013) Growth of Sale, investment, liquidity, profitability, dan size of Firm terhadap kebijakan dividend payout ratio pada perusahaan manufaktur yang terdaftar di Bursa Efek Indonesia, Jurnal Manajemen dan Akuntansi, Vol.2, No.1, p. 1-14.

Husnan, Suad. (2004). Dasar-dasar Teori PortofoliodanAnalisis Sekuritas. Yogyakarta: UPP AMP-YKPN.

Imam, Ghozali. (2005). Aplikasi Analisis Multivariate Dengan Program SPSS, Semarang: Badan Penerbit UNDIP, .

Kamaruddin, ahmad (2005) Akuntansi manajemen: dasar-dasar konsep biaya dan pengambilan keputusan. Jakarta : PT Raja Grafindo Persada.

Magister Akuntansi Universitas Pancasila. (2014) Pedoman Penyusunan Thesis : Jakarta.

Marietta, Sampurno. (2013) Analisis pengaruh cash ratio, return on assets, gowth, firm size, bebt to Equity Ratio terhadap Dividend Payaout Ratio: Studi Pada Perusahaan Manufaktur yang terdaftar di Bursa Efek Indonesia Tahun 2008-2011, Diponegoro Journal of Management Vol.2, No.3, p.23373792.

Pasaribu, Kowanda, Nawawi, 2014, Determinan Dividend Payout Ratio pada Emiten LQ 45 di Bursa Efek Indonesia, Vol.8 No.1 p 1-12. Raharjaputra,HendraSumantri.2009. Manajemen Keuangan dan Akuntansi untuk eksekutif Perusahaan. Jakarta: Salemba Empat.

Riyanto, Bambang. (2001) Dasar-dasar pembelanjaan perusahaan, yogyakarta: BPFE

Sartono, Agus. (2010) manajemen Keuangan "Teori dan Aplikasi". Edisi Keempat. Yogyakarta: BPFE.

Suhandak, Handayani. (2014) Pengaruh rasiorasio keuangan terhadap dividend payout ratio: pada perusahaan yang listing di BEI tahun 2009-2011, Jurnal Administarsi Bisnis, Vol.7, No.2, p.1-9.

Sutrisno. (2003). Manajemen Keuangan Teori, Konsep, dan Aplikasi. Yogyakarta: Penerbit Ekonisia

Van Horne, Wachowicz. (2002). Financial Management. Edisi keduabelas. Prentice Hall: Penerbit Upper Sadle River. 